\title{
Energy and sustainable development
}

\section{エネルギーと持続可能な発展}

\author{
Yohji UCHIYAMA \\ Institute of Engineering Mechanics and Systems, University of Tsukuba \\ 1-1-1 Tennohdai Tsukuba, Ibaraki 305-8573, Japan \\ TEL:+81-29-853-6194, FAX: +81-29-853-5207 e-mail: uchiyama@kz.tsukuba.ac.jp
}

( Received 8, May 2003 Accepted 23, June 2003 )

\begin{abstract}
A modern industrial society is highly depending on a huge amount of energy resources. The world energy consumption has been increasing year by year. It will be increasing with the economic growth of developing countries. Stable energy supply and environmental protection are absolutely essential for leading a high quality of life. A well-balanced utilization of energy resources must be achieved through "3Es" such as economic growth, stable energy supply and environmental preservation. Japan is attempting to develop new energies, including nuclear power, and increase its use of natural gas, while strengthening Japan's energy conservation policies. The new energy supply system in pursuit will serve as a model for other Asian countries as well, given the fact that they share various similarities with Japan, including the climate, the lack of energy sources, and vulnerability in energy supply.
\end{abstract}

Keywords: Sustainable development, economic growth, energy security, environmental protection

\section{1.わが国の経済成長とエネルギー消費}

エネルギーは、社会の経済発展と人々の生活レベルの 向上によって増大し続けている。江戸時代までは、多く の人々が「晴耕雨読」の自然に合わせたライフスタイル であったために、社会のエネルギー消費量はわずかであ つた。当時、煮炊きや風呂の燃料には薪が使われ、灯り には菜種油による行灯が利用されていた。農業や工業の 生産、そして人や物の移動に使われた動力源も家畜や人 間であった。エネルギー源は再生可能エネルギーだけで あった。しかし一方で、人々は冬の寒さや夏の暑さに耐 え忍び、水害や干ばつといった自然災害に脅えることも 多かった。

現代社会は、自然災害への対策、厳しい肉体労働から の解放、快適で便利な生活といった人々の要求や欲望を 充足する方向で発展している。その発展を支えているの が技術で、その進歩には目覚しいものがある。そういっ た技術の大半は製造と利用の過程において化石然料な どのエネルギーを大量に消費している。技術の発達は社
会の経済活動と人々の生活を支えている一方で、エネル ギーを大量に消費する社会を形成している。

一般に国の経済的な豊かさは、国民総生産（GNP）によ って示される。過去 1 世紀の間に、日本の GNP がどのよ うに変わったかを実質価格で示すと表 1 のようになる。 表には GNP のほかに人口とエネルギー消費量の推移も示 してある。1900 年から 1950 年までの半世紀で人口は 1.9 倍、経済成長は 2.7 倍、エネルギー消費は 4.5 倍にまで 増大している。一人あたりでみると経済成長は 1.4 倍、 エネルギー消費は 2.4 倍である。それに対して第二次世 界大戦から現在までの後半の半世紀で、わが国の経済成 長とエネルギー消費は著しく増大していることがわか る。1 世紀の間に経済成長は 44.4 倍、エネルギー消費 量は 53.2 倍にもなっており、人口の 2.9 倍をはるかに 超えている。この間の成長を一人あたりでみると、経済 成長は 15.4 倍、エネルギー消費量は 18.4 倍である。こ れからみても経済成長とエネルギー消費とには大きな 関わりがあることがわかる。 
Table 1. Economic and energy growth in Japan during the past century

\begin{tabular}{|c|c|c|c|c|c|}
\hline & $\begin{array}{c}\text { 人口 } \\
\text { [億人 ] }\end{array}$ & $\begin{array}{c}\text { GNP } \\
\text { [兆円] }\end{array}$ & $\begin{array}{c}\text { エ祙ギー消費 } \\
{\left[10^{18} \mathrm{~J}\right]}\end{array}$ & $\begin{array}{l}\text { 一人あたりの } \\
\text { GNP[万円/人] }\end{array}$ & $\begin{array}{c}\text { 一人あたりの } \\
\text { エ祃ギー消費 }\left[10^{9} \mathrm{~J} / \text { 人 }\right]\end{array}$ \\
\hline 1900 年 & $0.439(1.0)$ & $11(1.0)$ & $0.44(1.0)$ & $25(1.0)$ & $10.0(1.0)$ \\
\hline 1950 年 & $0.832(1.9)$ & $30(2.7)$ & $2.00(4.5)$ & $36 \quad(1.4)$ & $24.0 \quad(2.4)$ \\
\hline 2000 年 & $1.269(2.9)$ & 493 (44. 4) & $23.39(53.2)$ & $389(15.4)$ & $184.2(18.4)$ \\
\hline
\end{tabular}

（）内は 1900 年の数值に対する比率「エネルギー・経済統計要覧 2002」日本エネルギ一経済研究所から作成

わが国は昭和の初期までは、ほとんどの人は薪や廃材 など身近に得られる然料だけによって生活していた。戦 後、住宅や道路など社会基盤施設の整備と、自動車や家 電製品など耐久消費財の普及によって経済が急速に成 長するに伴って、石油や電力の消費が大幅に増大した。 1960 年頃、日本における舗装道路の割合はわずか $2.8 \%$ 、 道路のほとんどが砂利道であった。現在、道路の舗装率 は75\%である。自動車は 1960 年頃の 700 万台から、現 在は 10 倍以上の 7500 万台にまで普及している。1970 年 以前は、ワープロ、パソコン、VTR、CD プレーヤといっ た情報機器もなく、電子レンジ、衣類乾燥機、温水器、 電気カーペットもなかった。家庭の 1 世帯あたり毎月の 電力消費量は、1970 年で $152 \mathrm{kWh}$ であったが、1997 年に は約 3 倍の $446 \mathrm{kWh}$ にまで増加している。家電製品の普 及により家事労働は軽減された。戦前は、農家の女性 (31 〜 45 歳）の $17 \%$ は朝 4 時に起き、 5 時には $80 \%$ が起き て、一日中、家事と農作業に追われ、ホットする時間は 15 分程度だったという。今、日本の主婦が 1 日にテレビ をみる時間は平均で 4 時閒 40 分である。

\section{WISE 社会の構築に向けて}

わが国は戦後からの半世紀、「開発と成長」をモットー にして物質的な豊かさを求めて経済成長を推し進め、そ して様々な製品や技術を開発してきた。この間、GNPを始 めとする社会の指標はすべて右肩上がりであった。右肩 上がりの時代に大切なことは、量の効率的な確保であっ た。都市への人口と機能の集中、技術や工場の大型化、 そしてそれらを支える護送船団方式による組織体制が とられてきた。それらは規模の経済性を追求した社会シ
ステムで、右肩上がりで増大していた社会の需要を効率 的に満たすには最も有効な方法であった。

しかし1970 年代の石油危機を経て、さらに 1990 年代 に入ってバブル経済が弾けると、様相は一変した。それ まで続いていた成長指標の伸びが停滞し始めた。人々は わが国の社会が欧米と同じように物質的に成熟化段階 に入ったことを否が応でも自覚することになった。各都 市でこれまでに整備してきた建物や道路といった社会 基盤施設の規模は膨大で、その維持補修の大変さに気付 いた。また家庭では車や家電製品といった耐久消費財が 所狭しに家の中に詰め込まれ、もうこれ以上、物を増や していくのが難しくなってきている。

そういった中で、新しい潮流が社会に芽生えつつある。 それは、グローバル化、自由化、情報化、あるいは環境 意識の高まりなど人々の新しいコミュニケーションや 価值観を重視する発展である。右肩上がりの時代に対応 して築き上げられてきた日本の社会構造は根底から崩 れ始めている。新しい潮流の中で、産業、経済、科学技 術の新たな発展が求められている。

新たな発展は、右肩上がりの時代に流行った過去の傾 向から予測していくものではない。50 年後にはどうなっ ているかではなく、50 年後にはどうしたいかが問われて いる。つまり人々の意志によって、未来を創造していく 時代になる。

わが国の将来社会を考えるにあたって、“WISE”とい うキーワードが大切と考えている。Wise とは言うまでも なく英語で”賢い、思慮のある“の意である。ここでは 「福祉 (Welfare)」、「情報 (Information)」、「安全 (Safety)」、「環境 (Environment)」の頭文字をとってい 
る。21 世紀の日本に求められているのは人間性の回復、 情報メデイアによるコミュニケーションの発展、技術の 安全性、環境の保全といったより質の高い社会を構築し ていくことである。

\section{$2-1$. 福祉}

21 世紀の前半からわが国は少子・高齢化が急速に進 展する。少子・高齢化に備えて社会保障や福祉のあり方 が見直されつつある。活力ある社会を築いていくには、 高齢者が楽しめる文化、旅行、福祉といったサービスが 発展することが望まれる。他の世代に比べて大きなスト ックをもっている高齢者層が、社会活動に参加し生きが いを感じるようなモノやサービスの供給が大切になる。 例えば、シルバー人材センター、老人大学、バリアフリ 一・ホームエレベータ・介護ロボットなどを取り入れた 住宅環境対策、介護支援システムなどを充実していく。 またインターネットや地域コミュニテ組織を使うこと で若い世代とのコミュニケーションを高めていく工夫 もある。

21 世紀中葉になると開発途上国も先進国の後を追 うようにして高齢化社会に突入する。2 1 世紀は世界規 模で高齢者の生き方や福祉社会のあり方が問われる時 代になる。特に人口が多いアジア地域での高齢化は急速 に進むことが予想され、わが国はアジアの他の国々にと って模範となるような福祉社会を築いていくことが求 められている。

\section{2-2．情報}

物質やエネルギーに依存して発展する工業社会には 成長の限界がある。情報化の進展はその限界を乗り越え ていく可能性を秘めている。情報メデイアを使って人々 のニーズが的確かつ即座に掴めるようになれば、無䭾が 多い見込み生産が改善できる。鮮明な映像や音声が同時 に送られ双方向の通信が図れるようになれば、商品の選 択、人との交流、在宅勤務が容易となり、人や物の移動 を最小限にすることで大幅なエネルギー節約を図るこ とができる。本、雑誌、新聞を電子化していけば紙の消 費が減り、廃棄物量の削減だけでなく森林破壊を防ぐこ とにもなる。社会の産業や雇用も変わっていく。高度経
済成長期の雇用者の大半は工場でのブルーカラーであ った。その後、産業のサービス化とともに自動車、レジ ヤー、ホテル・レストラン、流通などの産業が急速に成 長し、雇用の中心は土場から業務、商業などホワイトカ ラーへと移っていった。そして今、新たに情報化の進展 により一部ではレインボーカラーとも呼ばれている新 しい雇用が創出されている。

これまでの社会の発展は、人の体にたとえれば、骨と 肉を成長させてきたことになる。問題は資源やエネルギ 一を使いすぎて社会が肥満状態になっていることだ。社 会の至る所に成人病が現れはじめている。脂肪を落とし てスリムにならなければ、心臟病、ガン、脳卒中など死 に至る恐れもある。情報化は、脳、神経系、五覚 (味覚、 視覚、聴覚、臭覚、触覚) に相当し、それらの機能を高 める働きがある。優れた脳細胞と強い神経をもち、五覚 機能のバランスと筋肉を鍛えることで人間性、安全性、 環境性、国際性を兼衫備えた人間（社会）が求められて いる。レインボーカラーの役割は、肥満した動きの鈍い 細胞を筋肉が締まった元気な若者の細胞に蘇らせるこ とだ。

\section{2-3. 安全}

技術が高度に発達した現代社会は、人々に豊かさと快 適さをもたらしているが、反面、過去には考えられなか ったリスクを発生している。航空機の墜落、原子力発電 所の放射線漏れ、タンカーの座礁、電車や自動車事故と いった技術リスク。火災や地震などの都市災害リスク。 強盗事件、サリン事件、テロ行為、核拡散への不安とい った犯罪リスク。騷音、重金属、ダイオキシン、遺伝子 組換え、ばいじん、酸性雨、温暖化などの環境リスク。 情報や金融機関におけるサイバーリスク・・。人間が 産みだした技術によってリスクの種類と範囲が広がっ ている。

高度技術社会ではリスクから逃れることはできない。 安心できる社会を維持していくにはリスク管理が不可 久であるということを忘れてはならない。その対策とし て、リスクをできるだけ発生させない、発生しても被害 を最小に抑える管理システムを社会に構筑していく必 
要がある。リスク管理に有能な技術者の育成も大切にな る。また住民や国民にリスクの知識、防止方法、発生時 対策について理解を深めていくリスクコミュニケーシ ヨンを図っていく必要もある。

\section{2-4. 環境}

物質的な豊かさを充足する発展は、大量生産と大量消 費が基本となっており、それによって大量の廃棄物が発 生する。大量廃棄が原因で社会の環境問題は、年ととも に深刻になってきている。それは、産業や生活の廃棄物 だけでなく、化石燃料の大量消費による酸性雨や地球温 暖化など、地球規模にまで広がっている。人類の 21 世 紀における持続可能な発展を考えると、先進国が造り上 げた大量生産と大量消費を改め、廃棄物量をできるだけ 少なくする社会システムを築かなければならない。

私たちは公共財としての水、空気、土を無料で利用し ている。それらを污染する大量生産と大量廃棄の世界を このまま放置していくと、污染によって地球はいずれ生 物が住めない環境へと変化してしまう。一旦破壊された 環境を修復していくことは容易でない。大規模な修復に は、巨額の資金を要するだけでなく、皮肉なことにエネ ルギーや資源も使わなければならない。破壊や污染する ものに対する規制と経済的な制裁が必要になる。陸上、 地下、海洋における資源の乱獲と環境破壊を防がなけれ ばならない。資源と環境保護のためには、経済外部性と
なっている水、空気、土の污染に対して、污染を防止す るためには環境負荷を内部化して経済メカニズムに取 り込むことが必要になる。それにより循環型社会を支え る環境ビジネスが世界の主要産業として成長していく ことになる。環境は理念だけで守れるものではない。守 るための経済メカニズムの創出が必要になることを忘 れてはいけない。

\section{3. 持続可能な発展にむけて}

20 世紀の世界は「開発と成長」をモットーに様々な製 品や技術を開発してきた。人々は物質的に豊かな社会を 築くことを目標にして経済活動を発展してきた。しかし、 経済を最優先に資源の大量消費で成り立つ物質文明に よって、人類は今、環境污染、温暖化、生態系の破壊、 あるいは資源枯渴といった問題に直面している。

世界が持続可能な発展を遂げていくためには、グロー バルかつ長期的な視点から環境、資源、経済というトリ レンマをいかに解決していくかが鍵となる。トリレンマ 問題は複雑なだけに、1つの方法だけで解決できるもの でない。可能な限り何枚も何枚も解決に向けた処方箋を 作っていくことが大切になる。対策は取り返しがつかな い事態が起きる前に実行しなければならない。その対策 は小手先で解決できるものでなく、痛みが伴う。 